\title{
Совершенствование рабочего процесса в гидроприводе культиваторов
}

\author{
С.Г. Пархоменко \\ Азово - Черноморский инженерный институт - \\ филиал ФГБОУ ВО Донского государственного аграрного университета \\ ( 2. Зернограде, Россия) e-mail: s-parkhom@mail.ru
}

\begin{abstract}
Исследования выполнены с целью совершенствования рабочего процесса гидравлических следящих систем почвообрабатывающих агрегатов. В современных условиях появляются новые требования к сельскохозяйственному гидравлическому приводу. Требуется совершенствование гидропривода. Существует несоответствие между параметрами гидравлического привода и его функциональным назначением. Необходим анализ рабочего процесса в гидроприводе машиннотракторных агрегатов при выполнении комплекса полевых работ в различных условиях эксплуатации. Рабочие органы должны перемещаться автоматически. В статье представлен анализ автоматических устройств, применяемых в машинах для обработки почвы. Следящие системы могут быть гидравлическими, электрогидравлическими и пневматическими. Механические системы не являются эффективными. Гидравлические системы дешевле электрических и пневматических. Они обеспечивают лучшие энергетические и качественные показатели технологического процесса обработки почвы. Проведён анализ рабочего процесса в гидроприводе культиваторов КСГ5 (Россия) и Н-7 (Германия). Рабочий орган для обработки почвы в ряду деревьев на культиваторе КСГ-5 представлен плоскорезной лапой. Культиватор Н-7 оснащён окучником. Выявлено несовершенство конструкции гидропривода культиватора КСГ-5. При работе наблюдаются отказы гидравлической следящей системы КСГ-5. Функционирование гидропривода культиватора КСГ-5 приводит к увеличению затрат энергии. В гидроприводе создаётся избыточное давление. Предлагается снизить затраты энергии за счёт разгрузки гидропривода. При определенном соотношении параметров механизма перемещения рабочие органы под действием сил сопротивления почвы стремятся в ряд многолетних насаждений и удерживаются в нём без использования гидропривода. Основная часть энергии расходуется на отвод посредством гидропривода рабочих органов из ряда насаждений.
\end{abstract}

Ключевые слова: гидропривод, давление, гидроцилиндр, гидрораспределитель, затраты энергии.

Постановка проблемы в общем виде и её связь с важными научными и практическими задачами. Научно-технологическое развитие страны является приоритетом государственной политики и должно осуществляться на основе трансформации науки и технологий, при высокой результативности исследований и их практического применения. В сложившихся условиях приоритет в исследованиях, высокий темп в получении новых знаний и в разработке инновационных рабочих органов для производства продукции растениеводства и плодоводства служат ключевыми фракторами, определяющими конкурентность экономики страны. Современные условия характеризуются недостаточной степенью внедрения отечественных садовых почвообрабатывающих машин, по причине невосприимчивости экономики к инновациям.

Анализ последних исследований и публикаций, в которых начато решение данной проблемы. Повышение эфрфективности с/х производства возможно только при использовании современных технических средств [1, 2] и проведения научных исследований на современном уровне [3-9]. В современных условиях с/х производства предполагаются существенные изменения в технологии обработки почвы [10], разработка новых рабочих органов [11], возникают принципиально новые требования к сельскохозяйственному гидроприводу.

Выделение нерешенных ранее частей общей проблемы. Гидропривод на основе раздельно-агрегатной системы несомненно сыграл положительную роль в развитии отечественной сельскохозяйственной техники. Однако к настоящему времени он морально устарел и не удовлетворяет возросшим требованиям сельскохозяйственного производства $[12,13]$. Возникает несоответствие между параметрами гидропривода и его функциональным назначением. Выявляются они при анализе протекания рабочего процесса в гидроприводе машин при выполнении комплекса полевых работ в различных условиях эксплуатации. 
Установлено, что управляемые гидравлической следящей системой рабочие органы при правильной регулировке не повреждают корневую систему и штамбы деревьев [14]. Следящие системы могут быть гидравлическими, электрогидравлическими и пневматическими. Механические системы не являются эффективными. Гидравлические системы дешевле электрических и пневматических. Они обеспечивают лучшие энергетические и качественные показатели технологического процесса обработки почвы.

Гидравлическим следящим устройством оснащены культиваторы Н-7 фрирмы "Холдер" (Германия) и КСГ-5 (Россия).

Рабочие органы культиватора Н-7 (окучник) и КСГ-5 (плоскорезная лапа), обрабатывающие почву в ряду деревьев, перемещаются посредством шарнирных механизмов.

Формулировка цели исследования. При работе машин для обработки почвы в садах наблюдаются отказы гидравлической следящей системы, связанные с чрезмерным нагревом масла [15-17]. Вынужденные простои для охлаждения масла влекут за собой увеличение времени организационно-технического обслуживания и снижение коэффициента использования времени смены. В этом случае возникает техническая задержка вследствие выполнения вспомогательных операций, связанных с охлаждением оборудования. Этим объясняется низкая производительность культиватора КСГ-5, функционирование которого сопровождается постоянным перегревом масла в гидравлической следящей системе [18].

По нагреву масла можно судить о расходе топлива трактором и затратах энергии в гидросистеме.

Цель исследования: снижение затрат энергии за счёт совершенствования рабочего процесса в гидроприводе культиваторов. Исследования выполнены с целью совершенствования рабочего процесса гидравлических следящих систем почвообрабатывающих агрегатов.

Основная часть. Проводились исследования рабочего процесса в гидроприводе культиваторов КСГ-5 (рис. 1).

До наезда щупа на штамб растения, (точка а на рис. 1), давление на входе в гидрораспределитель равно 4,3 МПа, на выходе 2,4 МПа. В поршневой полости гидроцилиндра давление поддерживается 2,8 МПа, в штоковой 3,7 МПа.

После наезда щупа на штамб растения золотник устанавливается в другое крайнее положение, и масло поступает в штоковую полость гидроцилиндра для поворота рабочего органа, точка $\boldsymbol{b}$. Давление на входе гидрораспределителя возрастает до $7,7 \mathrm{MПа}\left(\boldsymbol{b}_{\mathbf{2}}\right)$, в штоковой полости до 7,4 МПа $\left(\boldsymbol{b}_{1}\right)$. В связи с увеличением потока, сливающегося из поршневой полости гидроцилиндра, давление в ней становится 3,4 МПа $\left(\boldsymbol{b}_{4}\right)$. Давление в сливной гидролинии после гидрораспределителя почти не изменяется и остается равным 2,4 МПа.

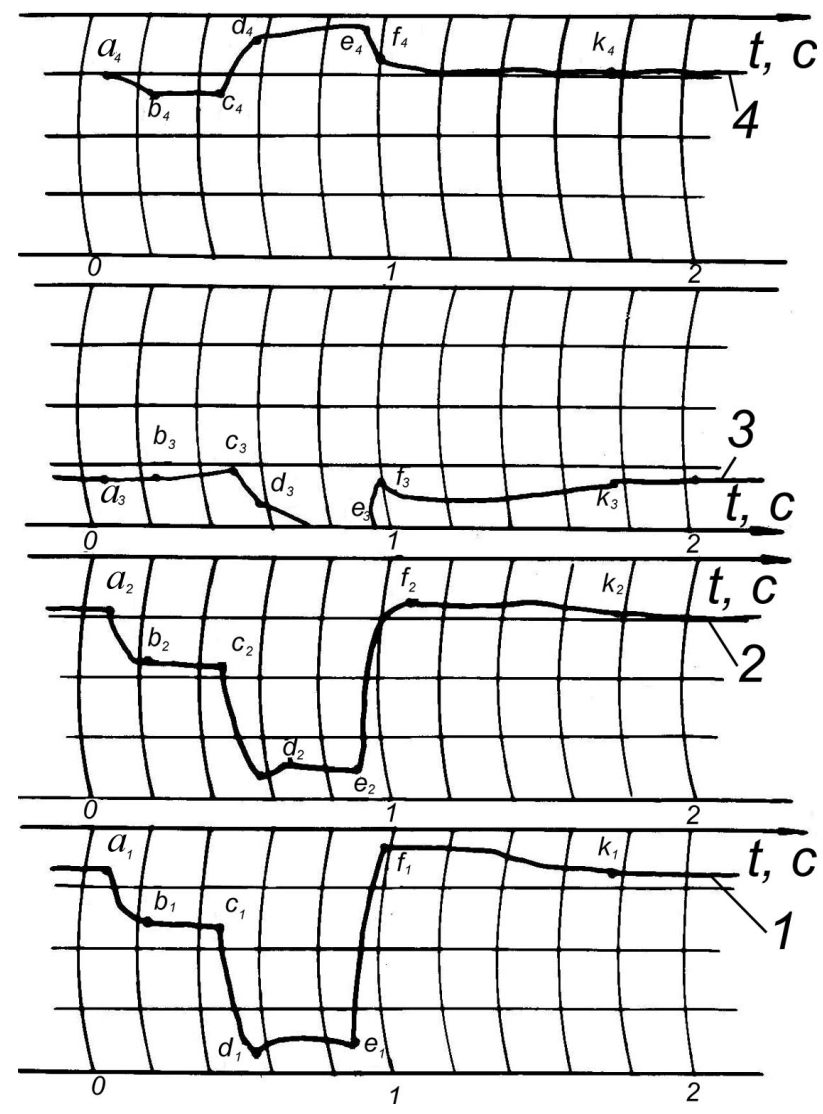

Рис.1. Рабочий процесс в гидроприводе культиватора КСГ-5: 1 - штоковая полость гидроцилиндра; 2 - вход гидрораспределителя; 3 - выход гидрораспределителя; 4 - поршневая полость гидроцилиндра

В момент времени, соответствующий точке c, щуп перестает перемещаться. В силу конструктивных особенностей гидросистемы и механизмов привода рабочего органа и золотника гидрораспределителя, рабочий орган удерживается в отведённом положении. Давление на входе гидрораспределителя и в штоковой полости возрастает до 13,8; 14,1 МПа (точки $\boldsymbol{d}_{\mathbf{1}}$ и $\boldsymbol{d}_{\mathbf{2}}$ ). Золотник гидрораспределителя находится в крайнем положении и масло через гидрораспределитель на слив не проходит $\left(\boldsymbol{d}_{3}\right)$. Такая ситуация возникает в силу наличия обратной связи между перемещениями штока гидроцилиндра и золотником гидрораспределителя. На основе этого рабочий орган в рабочем положении удерживается давлением подпора в поршневой полости гидроцилиндра. 
Это давление зависит от сдвига золотника от нейтрального положения, которое задается регулировочным винтом и обратной кинематической связью между перемещениями штока гидроцилиндра и золотника. В этом случае часть масла проходит через предохранительный клапан, а часть через гидрораспределитель. Их суммарная пропускная способность обеспечивает проход всего потока масла от насоса гидросистемы трактора. В момент времени, соответствующий точкам $\boldsymbol{c}, \boldsymbol{d}, \boldsymbol{e}$, когда щуп удерживается штамбом растения в отведенном положении, золотник полностью перекрывает проход маслу на слив.

Далее, когда щуп пройдет штамб растения, наблюдается первоначальная ситуация: золотник опять полностью не перекрывает слив маслу, которое дросселируется на нем, и создает необходимый перепад давления на кромках золотника для возврата рабочего органа в рабочее положение (точка $\boldsymbol{f}$ ). Давление в момент, соответствующий точке $\boldsymbol{f}$, меньше чем для точки а. Это указывает на то, что золотник гидрораспределителя удерживается в нейтральном положении. Так давление на выходе гидрораспределителя, точка $\boldsymbol{f}_{3}$, равно $2,3 \mathrm{MПа,} \mathrm{а} \mathrm{в} \mathrm{поршневой} \mathrm{полости}$ гидроцилиндра 2,5 МПа.

По мере завершения возврата рабочего органа в рабочее положение давление устанавливается прежним (точка $\boldsymbol{k}$ ).

Значения давлений в разных точках приведены в таблице 1.

Продолжительность отвода рабочего органа 0,28 с, удержания щупа - 0,37 с, возврата рабочего органа - 0,76 с.

Увеличение скорости движения агрегата не влияет на время отвода рабочего органа.

Время удержания щупа зависит от расстояния между культиватором и штамбом в этот момент и составляет 0,18...0,43 с. Рабочий процесс в гидроприводе левой и правой секциях культиватора Н-7 представлены на рис. 2.

При наезде при наезде на штамб щуп секции начинает отклоняться. Так как тяга золотника гидрораспределителя имеет самоподжимные шарниры, то сразу же начинает проворачиваться золотник. После поворота на угол $3,5^{\circ}$ вправо за счет изменения ширины щелей в гидрораспределителе справа и слева и дросселирования масла, шток гидрораспределителя начинает втягиваться через 0,06 с, точка аз (рис. 2). После поворота золотника на угол $5^{\circ}$ щель справа закроется (точка $\mathbf{a}_{4}$ ), и начинает поворачиваться корпус гидрораспределителя. Эта последовательность в работе гидрораспределителя подтверждается тем, что положение точек $\boldsymbol{a}_{\mathbf{4}}$ и $\boldsymbol{b}_{\mathbf{2}}$ совпадают во времени также, как и точек $\boldsymbol{a}_{3}$ и $\boldsymbol{b}_{1}$. Давление на входе гидрораспределителя достигает рабочего значения в точке $\boldsymbol{b}_{2}$, давление на выходе гидрораспределителя уменьшается в точке $\boldsymbol{b}_{1}$. Это связано с уменьшением потерь давления за счет увеличения щели слева.

Таблица 1. Значения давлений в гидроприводе культиватора КСГ-5

\begin{tabular}{|l|c|c|c|c|c|c|c|}
\hline $\begin{array}{l}\text { Место } \\
\text { установки } \\
\text { датчиков } \\
\text { давления }\end{array}$ & $\boldsymbol{a}$ & $\boldsymbol{b}$ & $\boldsymbol{c}$ & $\boldsymbol{d}$ & $\boldsymbol{e}$ & $\boldsymbol{f}$ & $\boldsymbol{k}$ \\
\hline $\begin{array}{l}\text { Вход гид- } \\
\text { рораспре- } \\
\text { делителя }\end{array}$ & 4,3 & 7,7 & 7,9 & 13,8 & 13,3 & 3,7 & 4,2 \\
\hline $\begin{array}{l}\text { Выход гид- } \\
\text { рораспре- } \\
\text { делителя }\end{array}$ & 2,4 & 2,5 & 2,9 & 0 & 0 & 2,3 & 2,2 \\
\hline $\begin{array}{l}\text { Поршне- } \\
\text { вая по- } \\
\text { лость гид- } \\
\text { роцилин- } \\
\text { дра }\end{array}$ & 2,8 & 3,4 & 3,6 & 1,4 & 1,0 & 2,5 & 2,8 \\
\hline $\begin{array}{l}\text { Штоковая } \\
\text { полость } \\
\text { гдроци- } \\
\text { линдра }\end{array}$ & 3,7 & 7,4 & 7,6 & 14,1 & 13,8 & 1,4 & 3,8 \\
\hline
\end{tabular}

Переключение золотника сопровождается переходным процессом, который вызывает колебания давления в гидрораспределителе (точки $b_{1}, k_{1}$ и $\left.c_{1}, c_{2}\right)$.

Когда рабочий орган полностью переместится вправо, первым заканчивает движение щуп (точка $\left.\boldsymbol{d}_{4}\right)$, затем втягивается шток гидроцилиндра и проворачивается корпус гидрораспределителя (точка $\left.\boldsymbol{d}_{3}\right)$. Длина участка $\boldsymbol{d}$-e зависит от скорости движения агрегата, длины и формы щупа.

После прохождения штамба щуп под действием пружины отклоняется влево, и с запаздыванием в 0,02 с начинает выдвигаться шток гидроцилиндра (точки $\boldsymbol{e}_{3}$ и $\boldsymbol{e}_{4}$ ).

Щуп в начальное положение возвращается значительно быстрее, чем отжимается штамбом. Но шток гидроцилиндра выдвигается и втягивается за одно и тоже время (0,33 c), хотя объем его поршневой полости больше в 1,33 раза объема штоковой полости. Это указывает на достаточную подачу масла в гидропривод культиватора Н-7 от насоса трактора.

Во время работы гидропривода левой секции через гидрораспределитель правой секции масло пропускается на слив, хотя переходные процессы в левой секции вызывают изменение давления и в правой (рис. 2).

Значение давлений при работе левой секции даны в таблице 2, температура масла в гидролиниях $34-38^{\circ} \mathrm{C}$. 


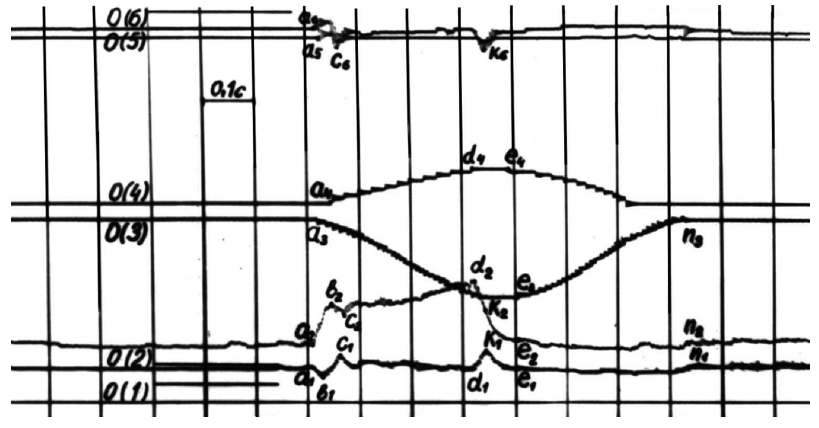

а) левая секция: 1 - выход левого гидрораспределителя; 2 - вход левого гидрораспределителя; 3 - перемещение штока гидроцилиндра; 4 - перемещение щупа; 5 - выход правого гидрораспределителя; 6 - вход правого гидрораспределителя

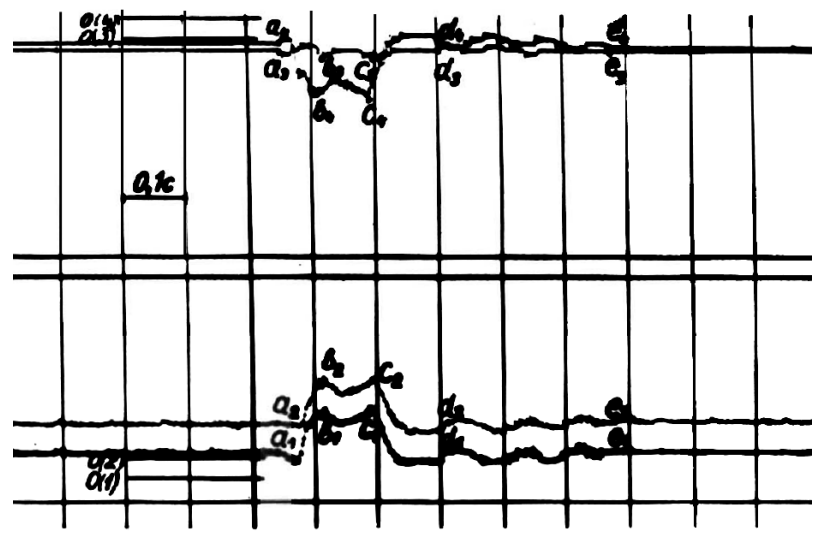

б) правая секция: 1 - выход левого гидрораспределителя; 2 - вход левого гидрораспределителя; 3 -выход правого гидрораспределителя; 4 - вход правого гидрораспределителя

Рис. 2. Рабочий процесс в гидроприводе культиватора $\mathrm{H}-7$

Таблица 2. Значения давлений в гидроприводе культиватора Н-7 (левая секция)

\begin{tabular}{|l|c|c|c|c|c|c|c|}
\hline Место уста- \\
$\begin{array}{l}\text { новки датчиков } \\
\text { давления }\end{array}$ & \multicolumn{6}{|c|}{ Давление в точке, МПа } \\
\cline { 2 - 8 } & $\boldsymbol{a}$ & $\boldsymbol{b}$ & $\boldsymbol{c}$ & $\boldsymbol{d}$ & $\boldsymbol{k}$ & $\boldsymbol{e}$ & $\boldsymbol{n}$ \\
\hline $\begin{array}{l}\text { Вход левого } \\
\text { гидрораспреде- } \\
\text { лителя }\end{array}$ & 2,2 & 5,6 & 4,7 & 7,5 & 5,0 & 2,5 & 2,4 \\
\hline $\begin{array}{l}\text { Выход левого } \\
\text { гидрораспреде- } \\
\text { лителя }\end{array}$ & 1,6 & 0,8 & 2,8 & 1,8 & 3,3 & 1,8 & 1,7 \\
\hline $\begin{array}{l}\text { Вход правого } \\
\text { гидрораспреде- } \\
\text { лителя }\end{array}$ & 1,4 & - & 2,8 & - & 3,0 & - & 1,4 \\
\hline $\begin{array}{l}\text { Выход правого } \\
\text { гидрораспреде- } \\
\text { лителя }\end{array}$ & 0,8 & - & 1,4 & - & 1,6 & - & 0,8 \\
\hline
\end{tabular}

Перепад давления между входом и выходом гидрораспределителя в начале втягивания штока 4 МПа и в конце - 5,7 МПа. Выдвижение штока происходит при значениях давления на входе 2,2 МПа и 1,6 МПа на выходе. Такие же значения давления и при несрабатывании следящего устройства. Это указывает на перемещение рабочего органа назад, в основном, под действием сил сопротивления почвы.

Значения давлений в различных точках для правой секции представлены в таблице 3, температура масла в гидролиниях $34-38^{\circ} \mathrm{C}$.

Моменту начала поперечного перемещения рабочего органа соответствует точка $\boldsymbol{a}$. Точка $\boldsymbol{b}$ отмечает перекрытие щели слива. Открытие слива в гидрораспределителе происходит в момент, соответствующий точке $\boldsymbol{c}$. Отвод рабочего органа правой секции производится в два раза быстрее, чем левой. Время прохождения штамба щупом правой секции равно 0,05 c, левой - 0,07 с. Возвращение рабочего органа начинается в момент времени, соответствующий точке $\boldsymbol{d}$, заканчивается в точке е. Рабочий орган правой секции возвращается в исходное положение за 0,28 c, а левой - за 0,33 с. Несмотря на более низкие значения давлений в различные моменты рабочего процесса, перепад давления в гидроцилиндре был в начале перемещения рабочего органа 4,2 МПа, в конце - 4,4 МПа.

Таблица 3. Значения давлений в гидроприводе культиватора Н-7 (правая секция)

\begin{tabular}{|l|c|c|c|c|c|}
\hline $\begin{array}{l}\text { Место уста- } \\
\text { новки датчиков } \\
\text { давления }\end{array}$ & \multicolumn{5}{|c|}{ Давление в точке, МПа } \\
\cline { 2 - 6 } & $\boldsymbol{a}$ & $\boldsymbol{b}$ & $\boldsymbol{c}$ & $\boldsymbol{d}$ & $\boldsymbol{e}$ \\
\hline $\begin{array}{l}\text { Вход левого } \\
\text { гидрораспреде- } \\
\text { лителя }\end{array}$ & 1,7 & 5,6 & 5,9 & 2,2 & 2,8 \\
\hline $\begin{array}{l}\text { Выход левого } \\
\text { гидрораспреде- } \\
\text { лителя }\end{array}$ & 0,8 & 5,0 & 5,4 & 2,2 & 2,3 \\
\hline $\begin{array}{l}\text { Вход правого } \\
\text { гидрораспреде- } \\
\text { лителя }\end{array}$ & 2,5 & 5,0 & 5,3 & 1,4 & 1,8 \\
\hline $\begin{array}{l}\text { Выход правого } \\
\text { гидрораспреде- } \\
\text { лителя }\end{array}$ & 2,0 & 1,4 & 1,3 & 0,8 & 0,9 \\
\hline
\end{tabular}

Характер рабочего процесса в гидравлическом следящем устройстве культиватора изменяется с увеличением скорости движения агрегата, только уменьшается время возврата рабочего органа. При скорости агрегата 1,5 м/с отвод рабочего органа левой секции происходит за $0,32 \ldots 0,35$ с, правой секции - 0,19...0,33 c; удержание в отведенном положении длится 
0,05...0,07 с. Возвращается в исходное положение рабочий орган левой секции за $0,31 \ldots 0,33$ c, правой - за 0,29...0,30 с.

Выводы и перспективы дальнейших разработок в данном направлении. Сравнение рабочего процесса в гидроприводе культиваторов позволило сделать вывод о несовершенстве конструкции КСГ-5. Необходимо обеспечить иное протекание рабочего процесса в гидроприводе культиватора КСГ-5 по аналогии с Н-7. Рабочий процесс должен характеризоваться повышением давления в штоковой полости гидроцилиндра только для отвода рабочего органа, а его возврат в ряд осуществляться под действием сил сопротивления почвы [19]. При определенном соотношении параметров механизма перемещения рабочие органы под действием сил сопротивления почвы стремятся в ряд многолетних насаждений и удерживаются в нем без использования гидропривода [20]. При этом давление в поршневой полости на протяжении возврата рабочего органа должно быть минимальным, что приведёт к существенному снижению затрат энергии [21]. Основная часть энергии расходуется на отвод посредством гидропривода рабочих органов из ряда насаждений.

\section{Литература}

1. Пархоменко, Г.Г. Комбинированные агрегаты для основной обработки почвы в засушливых условиях / Г.Г. Пархоменко, В.Б. Рыков // Достижения науки и техники АПК. - 2005. - №7. - С. 38-39.

2. Пархоменко, Г.Г. Машины для глубокой обработки почвы в засушливых условиях юга России / Г.Г. Пархоменко, В.Б. Рыков, В.И. Таранин // Техника и оборудование для села. - 2005. - №9. - C. 15-16.

3. Пархоменко, Г.Г. Исследование процесса трансформации почвообрабатывающих рабочих органов / Г.Г. Пархоменко // Механізація та електрифікація сільського господарства. - 2013. - T. 1. - C. 142-150.

4. Пархоменко, Г.Г. Экспериментальное исследование глубокорыхлителя для обработки почвы в междурядьях многолетних насаждений / Г.Г. Пархоменко, А.Н. Медовник, С.А. Твердохлебов // Международный технико-экономический журнал. - 2011. - № 3. - С. 76-78.

5. Пархоменко, Г.Г. Определение тягового сопротивления почвообрабатывающих машин / Г.Г. Пархоменко, В.Н. Щиров // Механизация и электрификация сельского хозяйства. - 2011. №8. - C. 23-24.
6. Пархоменко, Г.Г. Снижение тягового сопротивления глубокорыхлителей. / Г.Г. Пархоменко, В.А. Максименко, В.Н. Щиров // Сельский механизатор. - 2010. - №8. - С. 10-11.

7. Пархоменко, Г.Г. Сравнительная оценка энергетических показателей плуга садового чизельного с различными вариантами рабочих органов / Г.Г. Пархоменко, С.А. Твердохлебов // Вестник МичГАУ. - №3. - 2012. - С. 152-156.

8. Пархоменко, Г.Г. Расчёт взаимодействия катка с почвой с использованием теории вязкоупругости / Г. Г. Пархоменко, В. Н. Щиров // Тракторы и сельскохозяйственные машины. - 2007. №10. - C. 16-18.

9. Пархоменко, Г.Г. Теория глубокорыхлителя. / Г.Г. Пархоменко, В.Н. Щиров - Saarbrücken: LAP LAMBERT Academic Publishing, 2013. - 80 c.

10. Божко, И.В. Особенности безотвальной послойной обработки почвы в засушливых условиях / И.В. Божко, Г.Г. Пархоменко // Агротехника и энергообеспечение. - 2014. - № 1(1). - С. 25-30.

11. Божко, И.В. Кольцевой рабочий орган для обработки почвы / И.В. Божко, Г.Г. Пархоменко // Состояние и перспективы развития сельскохозяйственного машиностроения. Материалы 7-й международной научно-практической конференции в рамках 17-й международной агропромышленной выставки «Интерагромаш - 2014». - Ростов-на-Дону, 2014. - С. 78-81.

12. Патент 2231241 РФ А 01 В 35/32, А 01 В 39/28. Способ регулирования параметров колебаний вибрационных рабочих органов почвообрабатывающих машин и устройство для его осуществления / В.П. Богданович, Г.Г. Пархоменко, В.Б. Рыков, В.Н. Щиров. Заявитель и патентообладатель ГНУ ВНИПТИМЭСХ - Заявл. 07.12.2001. Опубл. 27.06.2004.

13. Патент 2486730 РФ А 01 В 35/00, А 01 В 35/20, А 01 В 39/20. Устройство для безотвальной обработки почвы / А.Н. Медовник, С.А. Твердохлебов, Г.Г. Пархоменко, Е.А. Светлова, И.А. Утка. Заявитель и патентообладатель ФГБОУ ВПО КубГАУ. - Заявл. 28.02.2012. Опубл. 10.07.2013.

14. Пархоменко, С.Г. Моделирование следящих систем почвообрабатывающих агрегатов. / С.Г. Пархоменко, Г.Г. Пархоменко // Тракторы и сельхозмашины. - 2017. - №1. - С. 22-31.

15. Пархоменко, Г.Г. Повышение эксплуатационной надёжности САР почвообрабатывающих машин / Г.Г. Пархоменко, С.Г. Пархоменко // Труды ГОСНИТИ. - 2016. - Т. 122. - С. 87-91.

16. Пархоменко, Г.Г. Теоретическое исследование механизмов перемещения рабочих органов для обработки почвы / Г.Г. Пархоменко, С.Г. 
Пархоменко // Интеллектуальные машинные технологии и техника для реализации Государственной программы развития сельского хозяйства: Сб. науч. докладов Междунар. научно-технич. конф. ФГБНУ ВИМ. - 2015. - С. 210-214.

17. Пархоменко, Г.С. Анализ рабочих режимов и расчёт на ПЭВМ состава тяговых машиннотракторных агрегатов / Г.С. Пархоменко, С.Г. Пархоменко, Г.Г. Пархоменко // Матер. XLII Междунар. научно-техн. конф. ФГОУ ВПО "Челябинский государственный агроинженерный университет". - Челябинск. - 2003. - С. 315-320.

18. Пархоменко, С.Г. Параметрическая оптимизация комбинированной следяще-силовой системы автоматического регулирования пахотного агрегата. / С.Г. Пархоменко, Г.Г. Пархоменко // Повышение эфффективности использования ресурсов при производстве сельскохозяйственной продукции - новые технологии и техника нового поколения для растениеводства и животноводства: сборник научных докладов Междунар. научно-практ. конф. - Тамбов, 2015. - С. 18-22.

19. Пархоменко, Г.Г. Совершенствование следящих систем почвообрабатывающих машин. / Г.Г. Пархоменко, С.Г. Пархоменко // Інженерія природокористування - 2017. - № 2 (8). - С. 56-62.

20. Пархоменко, Г.Г. Силовой анализ механизмов перемещения рабочих органов почвообрабатывающих машин по заданной траектории / Г.Г. Пархоменко, С.Г. Пархоменко // Тракторы и сельхозмашины. - 2018. - №1. - С. 47-54.

21. Пархоменко, Г.Г. Обоснование разработки энергосберегающего технического средства для обработки почвы в междурядьях садов одновременно с приштамбовой зоной / Г.Г. Пархоменко, А.В. Пономарев // Агроинженерная наука в сфере АПК: инновации, достижения: Сборник научных трудов VII Международной научно-практической конференции - Зерноград, 2012. - С. 71-76.

\section{References}

1. Parkhomenko, G. and Rykov, V. (2005). Kombinirovannye agregaty dlya osnovnoy obrabotki pochvy $\mathrm{v}$ zasushlivykh usloviyakh. Dostizheniya nauki i tekhniki APK, (7), pp.38-39.

2. Parkhomenko, G., Rykov, V. and Taranin, V. (2005). Mashiny dlya glubokoy obrabotki pochvy $v$ zasushlivykh usloviyakh yuga Rossii. Tekhnika i oborudovanie dlya sela, (9), pp.15-16.

3. Parkhomenko, G. (2013). Issledovanie protsessa transformatsii pochvoobrabatyvayushchikh rabochikh organov. Mekhanizacija ta elektryfikacija siljsjkogho ghospodarstva, 1, pp.142-150.
4. Parkhomenko, G., Medovnik, A. and Tverdokhlebov, S. (2011). Eksperimentalnoe issledovanie glubokorykhlitelya dlya obrabotki pochvy $v$ mezhduryadyakh mnogoletnikh nasazhdeniy. Mezhdunarodnyy tekhniko-ekonomicheskiy zhurnal, (3), pp.76-78.

5. Parkhomenko, G. and Shchirov, V. (2011). Opredelenie tyagovogo soprotivleniya pochvoobrabatyvayushchikh mashin. Mekhanizatsiya i elektrifikatsiya selskogo khozyaystva, (8), pp.23-24.

6. Parkhomenko, G., Maksimenko, V. and Shchirov, V. (2010). Snizhenie tyagovogo soprotivleniya glubokorykhliteley. Selskiy mekhanizator, (8), pp.10-11.

7. Parkhomenko, G. and Tverdokhlebov, S. (2012). Sravnitelnaya otsenka energeticheskikh pokazateley pluga sadovogo chizelnogo s razlichnymi variantami rabochikh organov. Vestnik MichGAU, (3), pp.152-156.

8. Parkhomenko, G. and Shchirov, V. (2007). Raschet vzaimodeystviya katka s pochvoy s ispolzovaniem teorii vyazkouprugosti. Traktory i selskokhozyaystvennye mashiny, (10), pp.16-18.

9. Parkhomenko, G. and Shchirov, V. (2013). Teoriya glubokorykhlitelya: Raschet vzaimodeystviya rabochikh organov $s$ pochvoy $v$ zasushlivykh usloviyakh. Saarbrücken: LAMBERT Academic Publishing.

10. Bozhko, I. and Parkhomenko, G. (2014). Osobennosti bezotvalnoy posloynoy obrabotki pochvy v zasushlivykh usloviyakh. Agrotekhnika i energoobespechenie, (1(1), pp.25-30.

11. Bozhko, I. and Parkhomenko, G. (2014). Koltsevoy rabochiy organ dlya obrabotki pochvy. In: Sostoyanie i perspektivy razvitiya selskokhozyaystvennogo mashinostroeniya. Materialy 7-y mezhdunarodnoy nauchno-prakticheskoy konferentsii v ramkakh 17-y mezhdunarodnoy agropromyshlennoy vystavki «Interagromash - 2014». Rostovon-Don, pp.78-81.

12. Bogdanovich, V., Parkhomenko, G., Rykov, V. and Shchirov, V. (2004). Sposob regulirovaniya parametrov kolebaniy vibratsionnykh rabochikh organov pochvoobrabatyvayushchikh mashin i ustroystvo dlya ego osushchestvleniya. 2231241 RF.

13. Medovnik, A., Tverdokhlebov, S., Parkhomenko, G., Svetlova, E. and Utka, I. (2013). Ustroystvo dlya bezotvalnoy obrabotki pochvy. 2486730 RF.

14. Parkhomenko, S. and Parkhomenko, G. (2017). Modelirovanie sledyashchikh sistem pochvoobrabatyvayushchikh agregatov. Traktory i selkhozmashiny, (1), pp.22-31.

15. Parkhomenko, G. and Parkhomenko, S. (2016). Povyshenie ekspluatatsionnoy nadezhnosti SAR pochvoobrabatyvayushchikh mashin. Trudy GOSNITI, 122, pp.87-91. 
16. Parkhomenko, G. and Parkhomenko, S. (2015). Teoreticheskoe issledovanie mekhanizmov peremeshcheniya rabochikh organov dlya obrabotki pochvy. In: Intellektualnye mashinnye tekhnologii i tekhnika dlya realizatsii Gosudarstvennoy programmy razvitiya selskogo khozyaystva. Moscow: FGBNU VIM, pp.210-214.

17 Parkhomenko, G., Parkhomenko, S. and Parkhomenko, G. (2003). Analiz rabochikh rezhimov i raschet na PEVM sostava tyagovykh mashinnotraktornykh agregatov. In: XLII Mezhdunar. nauchno-tekhn. konf.. Chelyabinsk: FGOU VPO "Chelyabinskiy gosudarstvennyy agroinzhenernyy universitet", pp.315-320.

18. Parkhomenko, S. and Parkhomenko, G. (2015). Parametricheskaya optimizatsiya kombinirovannoy sledyashche-silovoy sistemy avtomaticheskogo regulirovaniya pakhotnogo agregata. In: Povyshenie effektivnosti ispolzovaniya resursov pri proizvodstve selskokhozyaystvennoy produktsii - novye tekhnologii i tekhnika novogo pokoleniya dlya rastenievodstva i zhivotnovodstva. Tambov, pp.18-22.

19. Parkhomenko, G. and Parkhomenko, S. (2017). Sovershenstvovanie sledyashchikh sistem pochvoobrabatyvayushchikh mashin. Inzhenerija pryrodokorystuvannja, (2 (8), pp.56-62.

20. Parkhomenko, G. and Parkhomenko, S. (2018). Silovoy analiz mekhanizmov peremeshcheniya rabochikh organov pochvoobrabatyvayushchikh mashin po zadannoy traektorii. Traktory i selkhozmashiny, (1), pp.47-54.

21. Parkhomenko, G. and Ponomarev, A. (2019). Obosnovanie razrabotki energosberegayushchego tekhnicheskogo sredstva dlya obrabotki pochvy $v$ mezhduryadyakh sadov odnovremenno s prishtambovoy zonoy. In: Agroinzhenernaya nauka v sfere APK: innovatsii, dostizheniya: Sbornik nauchnykh trudov VII Mezhdunarodnoy nauchnoprakticheskoy konferentsii. Zernograd, pp.71-76.

\section{Анотація}

\section{Удосконалення робочого процесу в гідроприводі культиваторів}

\section{С.Г. Пархоменко}

Дослідження виконані з метою вдосконалення робочого процесу гідравлічних систем, що стежать грунтообробних агрегатів. В сучасних умовах з'являються нові вимоги до сільськогосподарського гідравлічному приводу. Потрібно вдосконалення гідроприводу. Існує невідповідність між параметрами гідравлічного приводу і його фрункціональним призначенням. Необхідний аналіз робочого процесу в гідроприводі машинно-тракторних агрегатів при виконанні комплексу польових робіт в різних умовах експлуатації. Робочі органи мають переміщуватися автоматично. У статті представлений аналіз автоматичних пристроїв, застосовуваних у машинах для обробки грунту. Стежать можуть бути гідравлічними, електрогідравлічними і пневматичними. Механічні системи не $\epsilon$ ефективними. Гідравлічні системи дешевше електричних і пневматичних. Вони забезпечують кращі енергетичні та якісні показники технологічного процесу обробки грунту. Проведено аналіз робочого процесу в гідроприводі культиваторів КСГ-5 (Росія) і Н-7 (Німеччина). Робочий орган для обробки грунту в ряду дерев при культиваторі КСГ-5 представлений плоскорізною лапою. Культиватор Н-7 оснащений окучником. Виявлено недосконалість конструкції гідроприводу культиватора КСГ-5. При роботі спостерігаються відмови гідравлічної системи, що стежить КСГ-5. Функціонування гідроприводу культиватора КСГ-5 призводить до збільшення витрат енергії. У гідроприводі створюється надлишковий тиск. Пропонується знизити витрати енергії за рахунок розвантаження гідроприводу. При певному співвідношенні параметрів механізму переміщення робочих органів під дією сил опору ґрунту прагнуть в ряд багаторічних насаджень і утримуються в ньому без використання гідроприводу. Основна частина енергії витрачається на відведення за допомогою гідроприводу робочих органів з ряду насаджень.

Ключові слова: гідропривід, тиск, гідроциліндр, гідророзподільник, витрати енергії.

\section{Abstract}

\section{Improving the workflow in the hydraulic drive of cultivators}

\section{S.G. Parkhomenko}

The studies were performed to improve workflow of hydraulic automatic control systems of the tillage units. In modern conditions there are new requirements to the agricultural hydraulic drive. Improved hydraulic drive is required. There is a mismatch between the parameters of the hydraulic drive and its functional purpose. It 
is necessary to analyze the working process in the hydraulic drive of machine-tractor units when performing a complex of field work under various operating conditions. Working bodies have to be moved automatically. The article presents analysis of automatic devices used into tillage machines. Automatic control systems can be hydraulic, electro-hydraulic and pneumatic. Mechanical systems are not effective. Hydraulic systems are cheaper electric and pneumatic. They provide best of energy and quality indicators of technological process of tillage. The analysis of the working process in the hydraulic drive of cultivators KSG-5 (Russia) and H-7 (Germany). The working body for tillage in a row of trees at the cultivator KSG-5 is represented by a flat-cut paw. The cultivator N-7 is equipped with an hiller. The imperfection of the design of the hydraulic drive of the cultivator KSG-5 is revealed. During operation, there are failures of the hydraulic automatic control system KSG-5. The operation of the hydraulic cultivator KSG-5 leads to an increase in energy costs. Overpressure is created in the hydraulic drive. It is proposed to reduce energy costs due to unloading the hydraulic drive. Under a certain ratio of the movement mechanism parameters, the working elements under the action of soil resistance forces, tend to a row of perennial plantations and are retained in it without the usage of the hydraulic drive. The main part of the energy is spent for retraction by means of hydraulic drive of working elements from a number of plantations.

Keywords: hydraulic drive, pressure, hydraulic cylinder, hydraulic distributor, energy costs.

\section{Бібліографічне посилання/ Bibliography citation: Harvard}

Parkhomenko, S. (2019). Improving the workflow in the hydraulic drive of cultivators. Engineering of nature management, (3(13), pp. 79 - 86.

Подано до редакції / Received: 12.03.2019 